tioning of the employment service after the war, to place the worker in a suitable job and, if possible, the job best suited to his capacities and skills.

\title{
Able to Work and Available for Work
}

\section{LOUISE F. FREEMANi}

THE mere fact of his being out of work is not the sole circumstance that makes a worker eligible for unemployment compensation under the present system. A worker must not only be unemployed; he must meet the other conditions for eligibility set up in his state's law. In establishing a system the legislatures were not bound to occupy the whole field of unemployment ${ }^{1}$ and the present unemployment compensation system does not. Present laws, for example, are designed to provide only for a benefit period of limited duration.? They are designed to compensate only those workers who are ordinarily employed, ${ }^{3}$ and only those who have been employed in certain kinds of establishments. ${ }^{4}$ Accordingly, there is a requirement in all state unemployment compensation laws that an individual to be eligible for compensation must have been employed in covered employment for a given number of weeks ${ }^{5}$ or have earned wages of a specified amount in covered employment ${ }^{6}$ in a specified past period. The effect of this requirement is

tion of public policy which follows the draft bill model, in concluding that where an employee is compelled because of disease to terminate employment because continuance would endanger his health and personal welfare, the termination is an involuntary rather than a voluntary act within the meaning of the statute. Fannon v. Federal Cartridge Corp., $18 \mathrm{~N}$. W. (2d) 249 (Minn. 1945). The decision is noteworthy because the suitable worl: provision which requires the director to consider the degree of risk to health, eafety and morals was used to negative contentions that such factors could be ignored in determining whether the individual left work voluntarily without good cause attributable to the employer, and in determining the application of two disqualification provisions which had been added by the legislature and which tended to condition the worlicr's benefit rights on ability to perform, and acceptance of, his former employment when offered

† Senior Attorney, Federal Security Agency.

1. Carmichael v. Southern Coal \& Colve Co., 301 U. S. 495, 519 (1937).

2. The duration of benefits varies under state laws; as of May 1,1945, eighteen state laws provide for uniform duration of benefits, the others provide for a variable duration from a minimum to a maximum number of weels. The average duration is about sistecn weeks.

3. Chamberlin, Inc. v. Andrews, 271 N. Y. 1, 2 N. E. (2d) 22 (1936), affd per curiam, 299 U. S. 515 (1936), reli'g denied, 301 U. S. 714 (1937).

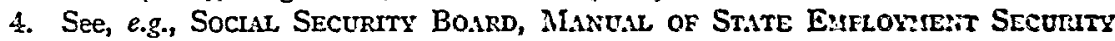
Legislation (Employment Security Memorandum No. 13, revised Nov. 1942) $\$\{$ 2(h), 2 (i).

5. As of January 1, 1945, Ohio (which has also an earnings requirement) and: Wisconsin used such a provision.

6. As of January 1, 1945. the laws of all the states (including Hawaii and Alastia) 
to test an individual's past attachment to the labor market. Present unemployment compensation laws are designed also to compensate only those individuals whose unemployment is due to a lack of suitable job opportunities. ${ }^{7}$ Accordingly, there is a requirement in all state laws to the effect that an individual to be eligible for benefits must be able to work and available for work. ${ }^{8}$

The availability requirement is said to be satisfied when an individual is willing, able, and ready to accept suitable work which he does not have good cause to refuse, ${ }^{9}$ that is, when he is genuinely attached to the labor market. ${ }^{10}$ 'Since, under unemployment compensation laws, it is the availability of an individual that is required to be tested, the labor market must be described in terms of the individual. A labor market for an individual exists when there is a market for the type of services which he offers in the geographical area in which he offers them. "Market" in this sense does not mean that job vacancies must exist; the purpose of unemployment compensation is to compensate for the lack of appropriate job vacancies. ${ }^{11}$ It means only that the type of services which an individual is offering is generally performed in the geographical area in which he is offering them.

except Wisconsin used such a provision. In 45 of these states the worker must have carned the qualifying amount during his base period.

7. See Harrison, Statutory Purpose and "Involuntary Unemployment," page 117 supra.

8. This eligibility requirement was derived from the British Unemployment Insurance Act which requires claimants to be "capable of and available for work." Unemployment Insurance Act, 1935, 25 Geo. V, c.8, $\$ 24(1)$. Not only were substantially the same words used in most state laws, but their meaning, as disclosed in the British cases, has generally been adopted as well. Generally, state laws require the individual to be "able to work and available for work"; in $\mathbf{3 4}$ of the $\mathbf{5 1}$ state laws such is the requirement (Alaska, Arizona, Arkansas, California, Colorado, Delaware, Florida, Georgia, Hawaii, Idaho, Illinois, Iowa, Kansas, Louisiana, Maryland, Mississippi, Nebraska, Nevada, New Hampshire, New Jersey, New Mexico, North Carolina, North Dakota, OHlahoma, Orcgon, Pennsylvania, South Carolina, South Dakota, Tennessee, Texas, Utah, Vermont, Virginia, and Wyoming). There are minor variations in six state laws (Connecticut, District of Columbia, Indiana, Kentucky, Missouri, and Montana); and more substantial variations in the other eleven (Rhode Island, Wisconsin, Maine, Massachusetts, Minnesota, West Virginia, Alabama, Michigan, Washington, Ohio, and New York). For example, the Wisconsin statute (Section 108.04) provides that "an employee shall be ineligible for benefits for any week in which he is with due notice called on by his current employer to report for work actually available within such week and is unavailable for work or physically unable to do his work"; the New York statute (LABOR LAW § 522) defines "total unemployment" as "the total lack of any employment on any day, caused by the inability of a claimant who is capable of and available for work to engage in his usual employment or in any other for which he is reasonably fitted by training and experience," including employment not subject to the act. (The references herein are to state laws as of January 1,1945.)

9. Ben. Ser. 8881-Conn. R and 8889-Fla. A (V7-11).

10. Ben. Ser. 8889-Fla. A (V7-11); Ben. Ser. 8419-Ill. R (V7-3). While the "labor market" concept has limitations, it will be used in this article, in so far as possible, in vicw of its widespread acceptance by tribunals.

11. See Ben. Ser. 8956-Conn. Ct. D (V7-12) in which the court said, "If a person has 


\section{Willing to Work.}

Normally an individual offers his services only in the performance of work which is suitable for him. While he may enlarge his labor market by his willingness to accept work that is not suitable, ${ }^{12}$ he should not be required to do so. ${ }^{13}$ To take any other riew would render nugatory the "suitable work" provisions of state statutes." In the Brown-Brockmeyer case, ${ }^{15}$ however, the Ohio court, talking an unnecessarily narrow view not only of the Ohio unemployment compensation law but of the very purpose of unemployment compensation, refused to interpret its law as requiring a claimant to be capable of and available for only suitable work. ${ }^{16}$ A claimant who had been suffering from colds quit work where she had been subject to severe drafts. Her job remained open for her thereafter. The court held that claimant has to be "capable and available for work she had been doing" unless the vacated job is not open, and, if it is not open, the claimant "must be available for some other employment for which she is reasonably fitted including employment not subject to this Act." The court added, "The word 'fitted' . . . refers to training or experience. It is not synonymous with the word 'suitable' ...." 17 The effect of such a

'exposed himself unequivocally to the labor market' he is available for work and eligible to receive benefits, even though there be no work available to him."

12. Ben. Ser. S659-Ark. R (V7-S) where claimant sought "any lind of vorl:."

13. Ben. Ser. S707-Ore. A (V7-S); Ben. Ser. 8681-Ky. A (V7-8).

14. This principle has been well expressed by the Pennsylvania Board of Reviev; Ben. Ser. S852-Pa. R (V7-10):

"Under the suitable work provisions a claimant is not disqualified by his refusal to accept every proffered employment, but only by his refucal to accept cmployment meeting the standard designated 'suitable.' It thus follows that he need not be available for every type of work but only for suitable work, for if by refusing unsuitable work he were held to have limited his availability, the suitable rorl: provisions would be rendered nugatory and meaningless. No point would have been served by the establishment of criteria to determine suitability if by the application thereof a person became disqualified under the availability provision. It ean only be concluded, therefore, that the availability provision is subordinate to the suitable work provisions, and that a perison is not disqualified on the grounds of nonavailability if he is available for suitable work."

Whether work is suitable depends upon the application to the individual of many factors, some of which are set forth in state unemployment compeneation laws in connection with the refusal of suitable work disqualification, and in the labor standards provisions. See Menard, Refusal of Suinble Work, page 134 infru.

15. Brown-Brockmeyer Co. v. Board of Rev., 70 Ohio App. 370, 45 N. E. (2d) 152 (1942).

16. The section of the Ohio unemployment compensation law governing the cass, 1 OnIo Gen. Code ANN. (Page, 1937) $\$ 1345-6$ (b), read as follows: "No individual ohall be entitled to any benefits unless he or she (1) Is capable of and available for rork; (2) Is unable to obtain work in his usual trade or occupation or any other employment for which he is reasonably fitted including employments not subject to this act . . . ."

17. 70 Ohio App. 370, 376-7, 45 N. E. (2d) 152, 155 (1942). 
decision is to tie a worker not only to his last occupation, but also, where the job is still open for him, to his last employer. Unemployment compensation was never intended to be used for the purpose of restricting the mobility of workers, nor was the availability requirement intended so to restrict a worker. Ohio's participation, pursuant to legislative authority, ${ }^{18}$ in the interstate benefit payment plan is evidence that it was contemplated that workers might leave the state and might nevertheless be entitled to benefits. Moreover, the court, in saying that it necessarily follows from claimant's not being "physically fit to do the work for which she was fitted by training and experience" that she was not available for work, ignores completely the fact that claimant may have been physically fit to do other work for which she was fitted by training and experience, or may even have been physically fit to do the same work in a shop where there were no drafts. On the basis of the court's reasoning, a claimant would be rendered unavailable for work by her refusal to return to her former job, even though she had had subsequent training which gave her a higher skill or other factors had intervened which made such former work unsuitable. The purpose of the availability requirement is to test a claimant's attachment to a labor market, not his attachment to one occupation or to one employer.

To say that an individual's labor market may properly be limited to work that is suitable for him, and that he must be available for work in his labor market, is not to say that he must be available for all suitable work. A claimant would not necessarily be unavailable merely because he limited the field of suitable work which he would accept, unless, as a result of his limitations, it could not be said that he was genuinely attached to a labor market. Any other criterion would make it possible to render ineligible almost any claimant by questioning him as to his willingness to accept, if offered, any number of possible jobs which, although they might be technically suitable, are not likely ever to be offered.' To impose on claimant the burden of deciding in vacuo whether he would be willing to accept any number of different kinds of work under varying circumstances at the peril of losing his benefits would be to exact an impossible condition of eligibility and would tend to substitute for objective standards the purely subjective reactions of the deputy or referee.

While consistent and repeated refusals of suitable work without satisfactory explanation might in themselves evidence a general unwillingness to work and show that a claimant is in truth unavailable for work, it would seem that ordinarily such unwillingness is not evidenced by claimant's unwillingness to accept a particular job or kind of suitable work. For example, changes in labor market conditions,

18. 1 Onio Gen. Code Ann. (Page, 1937) § 1345-19. 
over which the claimant has no control, present the problem of the effect on claimant's availability of his refusal to accept work at less than his highest skill, and at less than his highest prior earnings. During the war the question arose most often with reference to workers whose highest skills became decreasingly marketable as wartime restrictions on certain activities, such as construction work, became more severe and who refused work at lower skills, at lower pay. With the termination of the war, the problem is more often presented in considering the availability of workers who acquired new higherpaying skills during the war emergency, who have been laid off as a result of the curtailment of some war plant activities, and who refuse work in their old skills at lower wages. If it is considered that the worl: offered is suitable (and it is questionable that it should be), the problem to be resolved is whether such workers have so limited the field of suitable work which they will accept that they cannot be said to be genuinely attached to a labor market. This problem cannot be resolved, however, until the workers have had a reasonable time to explore the possibilities of obtaining work which meets their conditions. ${ }^{19}$ The worker might find that work which he is seeking, while not available in his present locality, is arailable in other localities to which he is willing to move, or that a short retraining course will make it possible for him to obtain a job in his own locality. To force a worker to accept a job at less than his highest skill at the peril of losing his unemployment compensation might result in the loss of this skill and is economic waste which should be aroided as long as there is a reasonable probability of its not being necessary. If, however, after a reasonable time, ${ }^{20}$ the worker is still unemployed, and there appears to be no prospect that the work which he is seeling will again be performed in his locality or in a locality to which he is willing to move, and he refuses to take other suitable work, he may properly be considered to have so limited the field of suitable work which he will accept as to negate his willingness to work..$^{21}$

These principles are generally applicable to the more difficult, but probably less common situation presented when there is no longer performed and there is no reasonable prospect that there will be performed any work that is suitable for an individual in his geographical labor area. In terms of the labor market it must be said that since there is no suitable work for the individual and the labor market for an individual is limited to suitable work, there is no labor market for such individual in that locality unless he extends it by his willingness

19. Ben. Ser. 9151-Kan. A (V8-2); Ben. Ser. 9131-Conn. R (VS-2).

20. Under a system where duration of benefits is limited, a reaconable time may be considered to be the entire benefit period. For a discussion of "reasonable time" sse Mienard, Refusal of Suitable Work, page $13 \frac{1}{2}$ infra, at 142.

21. Ben. Ser. 9151-Kan. A (VS-2). 
to take other work. It is questionable, however, that such individual is unavailable for work. 'He is not wilfully unemployed; the only reason he is not working is that no work is being performed which he can be reasonably expected to accept. Unemployment resulting from changes in labor market conditions would seem to fall within the unemployment that is intended to be compensated, for unemployment compensation is designed to assure a worker a reasonable opportunity to explore employment possibilities in his locality and in other localities to which he is willing to move.

\section{Able to Work.}

While, to be available for work, an individual must be willing to work (for, if he is not, his unemployment is due not necessarily to a lack of suitable job opportunities, but to his unwillingness to perform work), even complete willingness to work does not necessarily make one available for work. An individual must also be able to work.

Although the concept of ability to work is embraced in the term availability for work, all state unemployment compensation statutes have a separate eligibility requirement that a claimant must be able to work. " Able to work" is generally considered to relate to claimant's physical and mental capacity to perform remunerative work. ${ }^{22}$. The question presented, then, is how "able" must an individual be to be "able to work." Under most statutes, ${ }^{23}$ a claimant need not be able to do a particular job or a particular kind of work, ${ }^{24}$ nor need he be able to pursue his usual occupation. ${ }^{25}$ As in the availability requirement, an individual need only be able to do suitable work, ${ }^{26}$ and suitability varies with the physical condition of the claimant. A claimant who quit work upon the advice of her physician that the dust in the place where she worked affected her health, but who was certified by him as physically able to work in any occupation that was not dusty, was held available for work, ${ }^{27}$ as was a speeder tender in a textile mill, who left her job because of illness and who was later certified by the doctor as able to do light work, ${ }^{28}$ and a bakery employee, who because of his physical condition could not continue in his usual occupation, but who was able to accept and perform other services. ${ }^{29}$

22. If a claimant is not able to work, his unemployment is not necessarily due to a lack: of suitable job opportunities, but to his physical inability to perform work. See Ben. Ser. 9016-Pa. R (V7-12).

23. See note 8 supra.

24. Ben. Ser. 8524-R.I. A (V7-5).

25 Ben. Ser. 8973-Md. A (V7-12).

26. See cases cited in note 13 supra.

27. Ben. Ser. 7998-Pa. R (V6-6).

28. Ben. Ser. 8000-R. I. R (V6-6).

29. Ben. Ser. 2229-Neb. R (V2-12). 
On the other hand, the field of work which an individual is able to do cannot be so restricted that he is removed from the commercial labor market. Thus, a claimant who is able enough to perform only work in a highly specialized field of work in which a comparatively few people have ever been employed, may be considered to be removed from the labor market. ${ }^{30}$ So may a claimant who is unable to perform any work for which he is qualified, the only work he is able to do being work for which he is not qualified. ${ }^{31}$ However, a claimant, who had left her employment as an airplane worker because the lifting of heary airplane parts caused her to have severe backaches, but who was able and willing to accept suitable employment that did not require heary lifting, was held not to have removed herself from the commercial labor market and to be available for work. . $^{32}$

While economic conditions or competition with able-bodied men may render a claimant's chances of obtaining employment very small, that is immaterial as a test of ability to work. ${ }^{33}$ If, however, an individual's capacity for working has been so reduced that no one would employ him except out of motives of charity, he is not able to worls. 4 In short, the general principle should be that an individual is able to work, despite his age and physical condition, if there is a market in the geographical area in which he is willing to work for services which he is able to perform.

\section{Ready to Work.}

Besides being able and willing to work an individual, to be available for work, must be ready to work, for, if he is not, his unemployment is due not necessarily to a lack of suitable job opportunities, but to conditions which prevent his performing work. In both the British and American cases it is said that to be ready to work an individual's personal circumstances must leave him free to undertake suitable work and he must not be precluded by conditions created by him or beyond his control from accepting it. ${ }^{35}$ This requirement is the crux of the availability problem.

The following situations are typical:

1. Personal Circumstances of Claimant. The personal circumstances of a claimant who has to devote full time to the care of a sick member

30. Ben. Ser. $8819-0$ kla. $\mathrm{R}(\mathrm{V} 7-10)$. While this case dors not involve ability to vorls, the claimant had restricted the field of work which he would accept to worls in a highly specialized field in which only a few people had ever been employed.

31. Ben. Ser. 9030-W. Va. R (V7-12).

32. Ben. Ser. 8519-Kan. A (V7-5).

33. Ben. Ser. 2692-Ore. A (V3-2); Brit. Ump. 6655/35, Ben. Ser. (Gen. Supp. 1) BU-33.

31. Ben. Ser. 7998-Pa. R (V6-6); Ben. Ser. 8527-Wash. A (V7-5).

35. Ben. Ser. 2303-NIo. A (V2-12); Ben. Ser. 3099-N.D. A (V3-4); Brit. Ump. 7913/35, Ben. Ser. (Gen. Supp. 1) BU-1. 
of the family, and who can therefore not leave him to accept work, do not leave him free to undertake any work. He is removed from any labor market and is not available for work. ${ }^{36}$ On the other hand, if he has the care of the sick person only at night so that he is free to accept full-time work during the day, he should be considered available for work. There is no doubt as to claimant's readiness and willingness to work during the hours designated by him. Reduced to its basic issue, then, the question is whether the availability of a claimant whose availability is limited to specific hours is so reduced that in fact he is no longer available for work. The test in such cases is whether there is a market for his services during the hours that he offers them in the locality. ${ }^{37}$ If there is such a market, claimant should be regarded as available for work. ${ }^{38}$

2. Conditions Created by Claimant. The mere fact that a claimant is on a vacation away from his locality does not mean that he is precluded by conditions created by him from accepting suitable work. He might, for instance, have left a forwarding address with the employment office so that opportunities for suitable work could be promptly brought to his attention, and he might be willing to curtail his vacation to accept suitable work. ${ }^{39}$ On the other hand, if a claimant absents himself from his locality without leaving a forwarding address and does not register for work in the new place, he has by these omissions put himself beyond the reach of an employment office so that he might properly be considered to be unavailable for work. ${ }^{40}$

Similarly, mere attendance at a training school does not make an individual unavailable for work. Clearly an individual who is actually ready and willing at any time to interrupt his course to accept suitable work is available for work. ${ }^{41}$ An individual need not be available for all suitable work so long as his restrictions do not negate his willingness to work, ${ }^{42}$ and the very fact of his attendance at a training school

36. Ben. Ser. 8702-N.C. R (V7-8).

37. Ben. Ser. 3588-N.C. A (V3-6); Ben. Ser. 5172-N.J. A (V4-1); Ben. Ser, 5460Ohio A (V4-3).

38. For a discussion of the problem of "shift employment" see Altman and Lewis, Limited Availability for Shift Employment: A Crilerion of Eligibility for Unemployment Compensation (1944) 22 N.C. L. REv. 189.

39. Ben. Ser. 8908-Mich. R (V7-11); see also N. Y. Ref. Dec. 21-24-40R, Aug. 28, 1940, CCH Unemployment Ins. Serv. - N. Y. I 1950.09 (noncitizen, who was to become eligible for citizenship in six months, visiting mother in Canada but able to rcenter United States at any time held available for work).

40. See N. Y. App. Bd. Decs. 147-38, July 18, 1938, and 318-38, Nov. 28, 1938, CCH Unemployment Ins. Serv. $-N$. Y. T 1950.11 (departure on trip in search of employment without notifying employment office); Maine App. Trib. Dec. 38-AD-62, Dec. 22, 1938, $\mathrm{CCH}$ Unemployment Ins. Serv.-Maine $\$ 1950.08$ (departure on vacation).

41. Ben. Ser. 8043-Va. A (V6-6); N. Y. Ref. Decs. 27-56-40R, Jan. 8, 1940, and 524107-40R, May 22, 1940, CCH Unemployment Ins. Serv.-N. Y. II 1950.09 (students).

42. See pp. 126-7 supra. 
would appear to be evidence of willingness to work. Other pertinent factors to be considered in determining the suitability of work offered during a training course and an individual's availability for work include whether the training will enlarge his employment possibilities, whether he has the offer of a job upon completion of his course, and the length of time before the course will be completed. In such cases the factors affecting the question of availability should be carefully scrutinized to determine whether they overcome the prima facie effect of such trainee's registering for work at an employment office. So long as the trainee is ready and willing to accept suitable work, he should be considered to be available for work. ${ }^{43}$

3. Conditions beyond Control of Claimant. Even conditions beyond claimant's control may affect his availability. Thus, where there is no suitable work for claimant in the locality in which he lives, and he cannot reach his usual labor market area because of his inability to obtain transportation, he may properly be considered to be unavailable for work, ${ }^{44}$ unless he is willing to accept work that he can reach even though it does not meet the criteria of suitability or he is willing to move to some locality where work that is suitable for him is performed. This is another type of situation where a claimant should not be considered unavailable for work until he has had a reasonable opportunity to adjust to the changed condition..$^{45}$

An imprisoned claimant, even one illegally detained, is prevented by his incarceration from being exposed to job opportunities and from accepting any job. ${ }^{46}$ Similarly, an individual who is quarantined because of a contagious disease is thereby prevented from accepting any job during the period of his quarantine. 47 In such cases claimants, though willing to work, are not ready to work, even though they may be trained and able to perform various kinds of work for which there exist many job openings. Accordingly, during their confinement they are removed from any labor market and are unavailable for work.

Is the situation any different when, although an individual is not physically restrained, no employer may legally hire him to do work: which the individual is willing to perform? It appears that where employers are legally prohibited from hiring an individual, such individual is in substantially the same situation as is the imprisoned claimant, except that in place of the actual physical restriction on the claimant there is a legal restriction placed on the employer which, if

43. See Unemployment Compensation in the Reconzorsion Period: Recommendotions by the Social Security Board, Social Secunity Bulletrn, Oet. 1944, pp. 3, 7.

44. Ben. Ser. 8577-Ill. R (V7-6).

45. See-pp. 127-S supra.

46. Ben. Ser. 4111-N.D. A (V3-S).

47. N. Y. App. Bd. Dec. 1220-39, Nov. 24, 1939, CCH Unemployment Ins. ServN. Y. T 1950.10 (quarantined employee). 
disobeyed, will result in a sanction. In either case, despite the claimant's willingness to work and the existence of job opportunities, a legal restriction removes him from any labor market. ${ }^{49}$ It has been argued that legal restrictions on hiring should not affect the availability of workers since workers unemployed because of such restrictions are unemployed through no fault of their own. ${ }^{49}$ However, the fact that the circumstances which impinge upon a claimant's unemployment result from a set of circumstances over which he has no control is not determinative. Availability can be as effectively destroyed by circumstances for which the claimant is in no way responsible as by a set of conditions deliberately created by him. A claimant confined to bed through illness is not available for work, nor is a person who is inducted into the army. Yet in neither of these situations can it be said that the claimant is responsible for the conditions which have rendered him unavailable.

Government-imposed restrictions, however, generally prohibit the employment of a worker only under specified conditions. As such they will not affect his availability as long as there are other conditions under which the worker may be hired. For example, in some states government-imposed restrictions prohibit the employment of women in certain types of establishments within a specified number of weeks before or after child birth. ${ }^{50}$ While a woman subject to the statutory restriction may not be available for work of the type and in the establishments specified in the statute, it is necessary to determine whether she is available for other work. If she is able and willing to accept other work, and there is a market for the services which she is able and willing to perform, she may properly be considered to be available for work within the eligibility provisions of an unemploy. ment compensation law. ${ }^{51}$ To determine a claimant's availability for

48. N. J. Bd. of Rev. Dec. BR-5229, Feb. 14, 1944 (unpublished), in which it was said: "Section 4(c) of the Act requires claimants, in order to establish their cligibility for benefits, to be able and available for work. In the instant case, the appellant not only restricts her availability to the field of home work but, . . . there is no work available for home workers, inasmuch as government restrictions forbid employers from dispensing home work unless they receive the necessary certificate. Therefore, since the appellant was not available for work to be performed outside of her home and no work was available for the appellant to be performed in the home, we are of the opinion that the claimant is unavailable for work within the purview of Section 4(c) of the Act." See also Salavarria v. Murphy, 266 App. Div. 933, 43 N. Y. S. (2d) 899 (3d Dep't 1943); but of. Smith v. Murphy, 267 App. Div. 468,46 N. Y. S. (2d) 774 (3d Dep't 1944).

49. Smith v. Murphy, 267 App. Div. 468, 470, 46 N. Y. S. (2d) 774,775 (3d Dep't 1944); Mishaw v. Fairfield News, 12 Conn. Supp. 318 (Super. Ct., New Haven Cy., 1944).

50. See, e.g., Conn. Gen. Stat. (1930) §5201; 4 Mass. Ann. Laws (Michie, 1942) c. 149 , § 55; N. Y. LABOR LAW § 148; VT. Pub. LaWs (1933) § 6590.

51. See Brit. Ump. 1849/36, where claimant produced a medical certificate that she was capable of work, she was held to be capable of and available for work within four weeks of confinement though prior to confinement she had been in employment under the Factory 
work, the actual effect of the government-imposed restriction in the particular labor market area should be weighed and a conclusion reached as to whether the effect of such restriction is so to limit the field of work for which claimant may be hired as to result in his being removed from the labor market.

Where there is no legal prohibition against hiring an individual but employers for other reasons refuse to hire him, the problem is significantly different. While it is true that a restriction, whether it results from employers' refusals to hire an individual or from their being legally prohibited from hiring him, will have a serious effect on the likelihood of the individual's actually obtaining a job, it appears that a mere refusal to hire may properly be considered to have a different effect on a worker's availability than does a legal restriction on hiring..$^{52}$ Where employers refuse or are reluctant to hire an individual, suitable job opportunities which the individual is qualified to perform and which he is able, willing, and ready to accept may nonetheless exist. Such refusal to hire a worker does not of itself render the work unsuitable or prevent him from legally performing the vork. Accordingly, refusal of employers to hire married women, ${ }^{53}$ individuals beyond a certain age, ${ }^{54}$ or members of minority groups ${ }^{55}$ should not render unavailable individuals in any of such groups who are otherwise available. As a North Carolina appeals deputy has said, "An employer might not be willing to hire an individual if he does not like the way such individual walks, parts his hair, dresses, or because of his race, color, or creed, but so long as such individual is willing to accept work and is in a position to accept work, and has done nothing volitionally to lessen his chances of getting work, such an individual has met the test of the Law in being available for work." :s

The fact that employers' refusals to hire are reasonable should malie no difference. ${ }^{57}$ An individual's availability should not depend on the

and Workshop Act of 1901 and though under such act she could not be similarly employed for four weelss from the date of confinement and was, therefore, not available for the typa of work specifed in the act.

52. Ben. Ser. 3683-N.C. R (V3-6). A claimant who had been imprisancd and on his release denied employment because of a company rule against employment of any cae found guilty of violation of any criminal law of the state was found to be unavailable during his imprisonment but available thereafter.

53. Ben. Ser. 7935-Mass. R (V6-5).

54. Ben. Ser. 9141-Ill. R (VS-2); Olvla. App. Trib. Dec. 46 AT-43, Aug. 16, 19:3, $\mathrm{CCH}$ Unemployment Ins. Serv.-Olla. T 1950.034 (holding a 66-year old claimant available for work although prospective employers refused to hire him beeause of his advaneed age).

55. Ben. Ser. 9352-N. J. A (VS-4) (holding that although claimant was not hired because of his color, he was nonetheless available for worl:); see also Ben. Sar. 9170-Neb. $\mathrm{R}$ (V\&-2).

56. Ben. Ser. 9182-N.C. A (V8-2).

57. Ben. Ser. 2692-Ore. A (V3-2). 